ONLINE MUTATION REPORT

\title{
Prevalence of BRCA2 mutations in a hospital based series of unselected breast cancer cases
}

\author{
S-W Kim, C S Lee, J V Fey, P I Borgen, J Boyd
}

J Med Genet 2005;42:e5 (http://www.jmedgenet.com/cgi/content/full/42/1/e5). doi: 10.1136/jmg.2004.025056

$\mathrm{E}$ pidemiological data suggest that $7 \%$ of breast cancer cases and $10 \%$ of ovarian cancer cases in the general population are attributable to one or more autosomal dominant susceptibility alleles. ${ }^{1}$ The breast and ovarian cancer susceptibility genes BRCAI and BRCA2 were isolated in $1994^{2}$ and $1995,{ }^{34}$ respectively, and since then, a large volume of literature attests to the involvement of these genes in the great majority of ovarian cancers associated with dominant genetic predisposition, ${ }^{5}$ and a substantial, yet still poorly defined, proportion of such breast cancers. ${ }^{6}$ With respect to breast cancer, estimates of $B R C A$ attributable risk are based largely on analyses of populations with founder mutations and those affected by early onset breast cancer, and to a lesser extent, on analyses of unselected population or hospital based series of breast cancer cases.

The BRCA genes are very large and subject to a broad spectrum of mutations. ${ }^{78}$ Thus, population based estimates of the role of BRCA genes in breast cancer are more readily accomplished through the study of populations affected by a limited number of founder mutations. For example, the BRCA1 185delAG and 5382insC mutations and the BRCA2 6174delT mutation are present in $2.5 \%$ of Ashkenazi Jews, ${ }^{9-11}$ and account for approximately $30 \%$ of the early onset breast cancers and $12 \%$ of all breast cancers in this population. ${ }^{12}$ In Iceland, the founder mutation BRCA2 999del5 is present in $0.5 \%$ of the population, and accounts for $24 \%$ of early onset breast cancers and $8 \%$ of all breast cancers. ${ }^{13}{ }^{14}$ The contribution of BRCA mutations to breast cancer in outbred populations is difficult to extrapolate from these types of estimates, however. Towards that end, other studies have examined populations of women selected only for early onset breast cancer, with or without a family history. Representative data from this literature indicate that breast cancers in women aged $<45$ years are attributable to $B R C A l$ in $6-13 \%$ of cases and to BRCA2 in $4-5 \%$ of cases, suggesting that only $10-18 \%$ of early onset breast cancers are attributable to a $B R C A$ mutation. ${ }^{15-20}$ The largest population based study of BRCA mutation in breast cancer contained 1435 cases diagnosed before the age of 55 years in the UK, and found BRCA mutations associated with $2 \%$ of cases; $0.7 \%$ with $B R C A 1$ and $1.3 \%$ with BRCA2. ${ }^{21}$ In the only population based study of unselected breast cancer cases, BRCAl mutations were found in 3/211 American patients (1.4\%), and the BRCA2 mutation was not studied. ${ }^{22}$ Several hospital based series of unselected breast cancers implicate BRCAI and $B R C A 2$ in $2-5 \%$ and $0-2 \%$ of all cases, respectively, but these studies are limited by small sample sizes. ${ }^{23-26}$

Together, these data are consistent with the conclusion that $1-3 \%$ of all breast cancers in outbred populations are attributable to BRCAI. While it may be inferred from the population based studies of young women that the fraction of all breast cancers attributable to BRCA2 is smaller than for $B R C A 1$, there are insufficient data to support this conclusion directly. The purpose of this study was to determine the prevalence of germline $B R C A 2$ mutations in a relatively large,

\section{Key points}

- Existing estimates of BRCA2 mutation prevalence in breast cancer are based on studies of selected populations or small series of unselected cases. The purpose of this study was to determine the prevalence of BRCA2 mutations in a large hospital based series of unselected breast cancer cases in order to more reliably estimate the fraction of all breast cancers attributable to $B R C A 2$.

- The BRCA2 coding region and exon-intron junctions were screened by single strand conformation polymorphism and sequencing analyses for germline sequence variation in 490 unselected, prevalent cases of breast cancer from a single institution.

- A total of six (1.2\%) deleterious mutations were identified in the study population. Of these, five were the Ashkenazi Jewish founder mutation 6174delT, occurring in the subset of 90 Jewish patients (5.6\%). One in 400 (0.25\%) non-Jewish patients carried a deleterious BRCA2 mutation (corrected prevalence $0.37 \%$ ). In addition, 12 distinct rare polymorphic variants or variants of uncertain clinical significance were identified, along with several common polymorphic variants.

- These data suggest that $<0.5 \%$ of all breast cancers in the general population are attributable to inherited mutations in BRCA2.

hospital based series of unselected breast cancer cases to estimate the fraction of all breast cancers attributable to $B R C A 2$. We report here that this frequency appears to be $<0.5 \%$.

\section{METHODS}

\section{Population}

The patient population consisted of a subset of women diagnosed and treated for invasive breast cancer at this institution from 1973-2000. During the period December 1999 to July 2000, blood specimens were obtained from 501 unselected patients from this cohort following informed consent according to a protocol approved by the institutional review board. Data on age at diagnosis, menopausal status, ethnicity, year of diagnosis, histological diagnosis, type of surgery, and personal and family cancer history were obtained retrospectively from medical records. No family history information was available for five of the subjects. Following the attachment of these data to individual cases, all specimens were anonymised by removal of patient identifiers. Genomic DNA was isolated from blood samples using the QIAamp DNA blood maxi kit (Qiagen, Valencia, 
CA, USA), diluted in Tris-EDTA buffer, quantified, and stored at $-20^{\circ} \mathrm{C}$.

\section{Laboratory analysis}

The entire coding region (exons 2-27) and exon-intron junctions of BRCA2 were analysed by single strand conformation polymorphism (SSCP) analysis, followed by direct sequencing of all potential variants. Coverage of this region was accomplished using 65 PCR primer sets, which generated products ranging from 194 to $315 \mathrm{bp}$ in length. Primer sequences and annealing temperatures $\left(\mathrm{T}_{\mathrm{A}}\right)$ for PCR amplification of individual products are available upon request. Generally, PCR amplification for SSCP analysis was carried out in a volume of $10 \mu \mathrm{l}$ containing $50 \mathrm{ng}$ of genomic DNA, $1.5 \mathrm{mmol} / \mathrm{l} \mathrm{MgCl}_{2}, 50 \mathrm{mmol} / \mathrm{l} \mathrm{KCl}, 10 \mathrm{mmol} / \mathrm{l}$ Tris- $\mathrm{HCl}$, $\mathrm{pH}$ 8.3, $0.5 \mathrm{U}$ of AmpliTaq DNA polymerase (Applied Biosystems, Foster City, CA, USA), forward and reverse primers at $0.8 \mu \mathrm{mol} / \mathrm{l}$ each, dATP, dGTP, and dTTP at $200 \mu \mathrm{mol} / \mathrm{l}$ each, $20 \mu \mathrm{mol} / \mathrm{l}$ dCTP, and $0.25 \mu \mathrm{Ci}$ of $\left[\alpha-{ }^{33} \mathrm{P}\right] \mathrm{dCTP}(3000 \mathrm{Ci} / \mathrm{mmol})$. Amplification was for 35 cycles in a Perkin-Elmer 9600 thermal cycler, with each cycle consisting of 20 seconds at $94^{\circ} \mathrm{C}, 20$ seconds at $\mathrm{T}_{\mathrm{A}}$, and 30 seconds at $72^{\circ} \mathrm{C}$, with a 7 minute extension at $72^{\circ} \mathrm{C}$ following the last cycle. The entire reaction volume was then diluted into $30 \mu \mathrm{l}$ of denaturing loading buffer consisting of $95 \%$ formamide, $0.5 \mathrm{~mol} / \mathrm{l}$ EDTA, $0.02 \%$ xylene cyanol, and $0.02 \%$ bromophenol blue, heated at $95^{\circ} \mathrm{C}$ for 10 minutes, and cooled on ice for 10 minutes. Following this, $6 \mu \mathrm{l}$ of this solution were electrophoresed in gels consisting of $0.5 \times \mathrm{MDE}$ solution (BMA, Rockland, ME) in $0.6 \times$ Tris-borate-EDTA buffer at $6 \mathrm{~W}$ for 16 hours at room temperature. Following electrophoresis, gels were dried and exposed to a phosphor screen, which was analysed using a Molecular Dynamics Storm 860 PhosphorImager.

Potential sequence variants identified by altered electrophoretic mobility in SSCP analyses were excised from gels and eluted into $40 \mu \mathrm{l}$ of water for 24 hours at $4^{\circ} \mathrm{C}$, then $2 \mu \mathrm{l}$ of the eluted DNA sample were used as a template for subsequent PCR amplification using appropriate primers and reaction conditions identical to those described above, except that all dNTPs were at $200 \mu \mathrm{mol} / \mathrm{l}$, and radiolabelled dCTP was omitted. Products were electrophoresed in low melting point agarose, visualised with ethidium bromide, excised from gels, and purified using the QIAquick gel extraction kit (Qiagen). These purified DNA products were subjected to sequence analysis using an ABI BigDye terminator kit and a Prism 377 automated DNA sequencer (Applied Biosystems). Sequence variants were designated according to recommendations of the HUGO Nomenclature Working Group, using the sequence listed in GenBank accession \#U43746 as a reference, and were deposited in the Breast Cancer Information Core Database. ${ }^{8}$

\section{RESULTS}

A total of 501 patients meeting the study entry criteria provided informed consent and a blood specimen, and of these, 11 were excluded because of inadequate quantity or quality of the DNA sample obtained. Clinical and pathological information associated with the remaining 490 cases analysed for BRCA2 mutation is summarised in table 1 . The median age of the study population was 57 years (range 2785 ). The majority of patients (approximately 69\%) were $>50$ years and post-menopausal at the time of diagnosis. Two thirds were white, while another $18 \%$ were self described as "Jewish", approximately $95 \%$ of whom, at this institution, are estimated to be of Ashkenazi (eastern European) descent. Nearly all of the patients had been diagnosed with breast cancer within 5 years of providing a blood specimen. With respect to cancer history, $90 \%$ had no previous personal
Table 1 Characteristics of study population

\begin{tabular}{|c|c|c|}
\hline & No. & $\begin{array}{l}\% \text { of total } \\
(n=490)\end{array}$ \\
\hline \multicolumn{3}{|l|}{ Age at diagnosis (years) } \\
\hline $25-39$ & 42 & 8.6 \\
\hline $40-49$ & 112 & 22.9 \\
\hline $50-59$ & 148 & 30.2 \\
\hline $60-69$ & 112 & 22.9 \\
\hline $70-85$ & 76 & 15.5 \\
\hline \multicolumn{3}{|l|}{ Menopausal status } \\
\hline Premenopausal & 154 & 31.4 \\
\hline Postmenopausal & 336 & 68.6 \\
\hline \multicolumn{3}{|l|}{ Ethnicity } \\
\hline White (non-Jewish) & 329 & 67.1 \\
\hline Ashkenazi Jewish & 90 & 18.4 \\
\hline African American & 30 & 6.1 \\
\hline Hispanic & 17 & 3.5 \\
\hline Asian & 17 & 3.5 \\
\hline Unknown & 7 & 1.4 \\
\hline \multicolumn{3}{|l|}{ Year of diagnosis } \\
\hline $1973-1994$ & 10 & 2.0 \\
\hline $1995-2000$ & 480 & 98.0 \\
\hline \multicolumn{3}{|l|}{ Type of surgery } \\
\hline Lumpectomy & 323 & 65.9 \\
\hline Mastectomy & 167 & 34.1 \\
\hline \multicolumn{3}{|l|}{ Histopathological diagnosis } \\
\hline Infiltrating ductal carcinoma & 415 & 84.7 \\
\hline Infiltrating lobular carcinoma & 48 & 9.8 \\
\hline Mixed carcinoma & 27 & 5.5 \\
\hline \multicolumn{3}{|l|}{ Personal history of cancer } \\
\hline Bilateral invasive breast cancer & 16 & 3.3 \\
\hline Ovarian cancer & 0 & 0 \\
\hline Other cancer & 37 & 7.6 \\
\hline \multicolumn{3}{|l|}{ Family history of cancer $(n=485)$} \\
\hline Breast cancer & 199 & 41.0 \\
\hline First degree relative & 96 & 19.8 \\
\hline Second degree relative & 80 & 16.5 \\
\hline Third degree relative & 23 & 4.7 \\
\hline Male breast cancer & 5 & 1.0 \\
\hline Ovarian cancer & 19 & 3.9 \\
\hline Breast and ovarian cancer & 7 & 1.4 \\
\hline
\end{tabular}

cancer diagnosis (other than breast), while approximately $60 \%$ had no stated family history of breast or ovarian cancer. The majority of patients were diagnosed with infiltrating ductal carcinoma and had undergone breast conserving surgery.

Of the 490 cases screened completely for BRCA2 sequence variants, six $(1.2 \%)$ were found to harbour clearly deleterious mutations (table 2). Five of these were the founder mutation 6174delT, occurring with a prevalence of $5.6 \%$ in the subgroup of 90 Ashkenazi Jewish patients. The one additional mutation, 9132delC, was detected in a non-Jewish white patient and is a recurrent mutation that has been previously reported many times. ${ }^{8}$ Of these six patients, two were post-menopausal, none had a personal history of cancer (other than breast), and three had no family history of breast or ovarian cancer.

Twelve additional, relatively uncommon, distinct sequence variants were identified in 15 additional patients (table 2). These variants, none of which are predicted to cause deleterious protein truncation, may be classified as likely polymorphisms or "unclassified variants" depending on the nature of the sequence variation. Of the 12 distinct variants, two nucleotide substitutions $(2166 \mathrm{C} \rightarrow \mathrm{T}$ and $10338 \mathrm{G} \rightarrow \mathrm{A})$ are designated as polymorphisms based on the absence of an amino acid change, while the remaining 10 are designated as unclassified variants, based on the low probability of a functional effect on the encoded protein and no published evidence to the contrary. Three of the unclassified sequence variants detected in this study (V3091S, IVS9-90A $\rightarrow \mathrm{G}$, and IVS15-114delAGT) have not previously been reported. ${ }^{8}$ In 
Table 2 BRCA2 sequence variants

\begin{tabular}{|c|c|c|c|c|c|c|}
\hline \multirow{2}{*}{$\begin{array}{l}\text { Case } \\
\text { no. }\end{array}$} & \multirow[b]{2}{*}{ Variant } & \multirow{2}{*}{$\begin{array}{l}\text { Age } \\
\text { (years) }\end{array}$} & \multirow[b]{2}{*}{ Eth* } & \multicolumn{3}{|c|}{ Family history } \\
\hline & & & & FB & MB & 0 \\
\hline \multicolumn{7}{|c|}{ Deleterious mutations } \\
\hline 50 & 6174delT & 70 & J & 0 & 0 & 0 \\
\hline 148 & 6174delT & 54 & J & 0 & 0 & 0 \\
\hline 208 & 6174delT & 41 & J & 0 & 0 & 0 \\
\hline 307 & $9132 \mathrm{delC}$ & 45 & W & 2 & 0 & 0 \\
\hline 383 & 6174delT & 45 & J & 2 & 1 & 0 \\
\hline 461 & 6174delT & 41 & J & 3 & 0 & 1 \\
\hline \multicolumn{7}{|c|}{ Variants of uncertain significance } \\
\hline 43 & Dl420Y/10323delCins 11 & 70 & W & 0 & 0 & 0 \\
\hline 91 & $2166 \mathrm{C} \rightarrow \mathrm{T}$ & 53 & W & 1 & 0 & 0 \\
\hline 111 & IVS9-90A $\rightarrow G$ & 48 & W & 0 & 0 & 0 \\
\hline 116 & S1172L & 58 & W & 0 & 0 & 0 \\
\hline 149 & D1420Y & 61 & W & 2 & 0 & 0 \\
\hline 219 & I2944F & 71 & $A A$ & 1 & 0 & 0 \\
\hline 246 & $10338 G \rightarrow A$ & 61 & W & 3 & 0 & 0 \\
\hline 267 & T30131 & 48 & W & 2 & 0 & 0 \\
\hline 307 & $\mathrm{~K} 2950 \mathrm{~N}$ & 45 & W & 2 & 0 & 0 \\
\hline 331 & IVS15-114delAGT & 79 & $\mathrm{~J}$ & 0 & 0 & 0 \\
\hline 386 & I2944F & 45 & $\mathrm{H}$ & 0 & 0 & 0 \\
\hline 475 & I2944F & 58 & AA & 0 & 0 & 0 \\
\hline 482 & $10338 \mathrm{G} \rightarrow \mathrm{A}$ & 67 & W & 0 & 0 & 0 \\
\hline 516 & IVS24-16T $\rightarrow$ C & 38 & $A$ & 0 & 0 & 0 \\
\hline 517 & V3091S & 30 & W & 0 & 0 & 0 \\
\hline
\end{tabular}

*Eth., ethnicity; A J, Ashkenazi Jewish; C, non-Jewish white; AA, African American; $H$, Hispanic; $A$, Asian. †Number of first, second, or third degree relatives with female breast (FB), male breast (MB), or ovarian (O) cancers.

addition to the relatively uncommon polymorphic and unclassified sequence variants listed in table 2, several common polymorphisms were also detected, and two $(3624 \mathrm{~A} \rightarrow \mathrm{G}$ and IVS21-66T $\rightarrow \mathrm{C}$ ) were characterised by sequence analysis in this study.

\section{DISCUSSION}

The results of this study suggest that in the general outbred population, germline mutations of the BRCA2 gene account for less than $0.5 \%$ of all invasive breast cancers. However, the actual prevalence observed in this study $(0.25 \%)$ is likely to be somewhat of an underestimate, and must be qualified in several respects. Firstly, the screening technique used, SSCP analysis, is an indirect mutation screen with less than complete sensitivity. In a recent evaluation of mutation detection techniques directed toward the BRCAl gene, the same protocol for SSCP analysis used in this study, in the same laboratory, was found to have $67 \%$ sensitivity. ${ }^{27}$ Thus, a corrected prevalence estimate, assuming the same sensitivity for BRCA2 mutation detection, would be $0.37 \%$. Secondly, all of the polymorphic and unclassified sequence variants detected in this study were assumed to be unrelated to disease. Although there is currently no evidence to support a deleterious effect on BRCA2 protein function for any of these variants, this assumption may be incorrect for some. Thirdly, the PCR based procedures used in the great majority of mutation screening studies fail to detect large genomic deletions or rearrangements that are known to occur in the $B R C A$ genes. For BRCA2, however, only one such disease associated mutation, a large deletion affecting exon 3 in one Swedish breast and ovarian cancer family, ${ }^{28}$ has been reported to date.

With respect to the population examined in this study, several additional factors could affect the BRCA2 mutation prevalence estimate. Firstly, this estimate was derived from a hospital based, not population based series of cases. Compared with the breast cancer population in the USA generally, non-Jewish whites were over-represented relative to African American and other ethnic minorities in this study. However, there is no evidence to suggest that the BRCA2 mutation frequency is substantially different among these various outbred populations. In contrast, as summarised in the introduction, a BRCA2 founder mutation occurs at relatively high frequency in the Ashkenazi Jewish population and accounts for a proportionately higher fraction of all breast cancers in this group; the frequency of $5.6 \%$ observed in this study is consistent with previous estimates based on unselected cases of breast cancer in Ashkenazi Jews. ${ }^{12} 2930$ Secondly, the breast cancer patients in this series were all alive at the time of study entry, and so the proportion of cases attributable to BRCA2 would be artefactually low if germline BRCA2 mutation was associated with a substantially shorter survival than all breast cancers. While this may be true for $B R C A 1$ linked breast cancers, available evidence suggests that this is probably not the case for BRCA2 linked breast cancers, which more closely resemble their sporadic counterparts in many clinicopathological respects, including hormone receptor expression. ${ }^{31}$ Finally, other clinicopathological characteristics of the cases in this study such as age at diagnosis and histological subtype distribution are typical of those for the breast cancer population generally, and are unlikely to have affected the BRCA2 mutation prevalence estimate.

The BRCA2 attributable breast cancer incidence estimated in this study of unselected breast cancer cases is consistent with extrapolations from studies of selected groups of breast cancer patients, in which $B R C A 2$ mutations generally account for a smaller fraction of cases than BRCAl mutations. ${ }^{15-21}$ The data presented here, together with the population based study of unselected breast cancers attributable to BRCAI, ${ }^{22}$ suggest that $<4 \%$ of all breast cancers are associated with inherited mutations in BRCA1 or BRCA2, leaving a considerable proportion (approximately half) of the estimated dominant genetic attributable risk for breast cancer unaccounted for.

While there may exist one or more additional highly penetrant breast cancer susceptibility alleles ("BRCA3"), this possibility seems increasingly remote in light of the sustained lack of demonstrable linkage of non-BRCA linked breast cancer families to any other genetic locus. ${ }^{32}$ Another possibility is that the familial clustering of breast cancer in kindreds without BRCA mutations reflects the combined effects of multiple moderate or low penetrance susceptibility alleles-that is, that breast cancer susceptibility represents a polygenic trait. ${ }^{33}$ Indeed, there is considerable evidence to suggest that a high proportion, and perhaps the majority, of breast cancers arises in a susceptible minority of women. ${ }^{34-36}$ However, case-control studies examining the relative risks associated with individual candidate polymorphic alleles have generally failed to provide strong evidence of low penetrance breast cancer susceptibility genes, ${ }^{37} 38$ although the great majority of such studies were probably underpowered to reliably detect modest increases in relative risk. ${ }^{39}$ Further progress in this area will likely depend on novel strategies for elucidating the combined effects of multiple low penetrance alleles using non-candidate gene approaches such as genomewide expression profiling. ${ }^{40}$

\section{ACKNOWLEDGEMENTS}

This work was supported by grants from the W M Keck Foundation, the Breast Cancer Alliance, and the US National Institutes of Health (R01 CA71840).

\footnotetext{
Authors' affiliations

S-W Kim, C S Lee, J V Fey, P I Borgen, J Boyd, Gynecology and Breast Research Laboratory and Breast Service, Department of Surgery, Memorial Sloan-Kettering Cancer Center, New York 10021, USA J Boyd, Clinical Genetics Service, Department of Medicine, Memorial Sloan-Kettering Cancer Center, New York 10021, USA
} 
Correspondence to: Dr J Boyd, Department of Surgery, Box 201, Memorial Sloan-Kettering Cancer Center, 1275 York Ave, New York, NY 10021, USA; boydj@mskcc.org

Received 8 July 2004

Accepted 2 September 2004

\section{REFERENCES}

1 Claus EB, Schildkraut JM, Thompson WD, Risch NJ. The genetic attributable risk of breast and ovarian cancer. Cancer 1996;77:2318-24.

2 Miki Y, Swensen J, Shattuck-Eidens D, Futreal PA, Harshman K, Tavtigian S, Liu Q, Cochran C, Bennett LM, Ding W, Bell R, Rosenthal J, Hussey C, Tran T, McClure M, Frye C, Hattier T, Phelps R, Haugen-Strano A, Katcher $\mathrm{H}$, Yakumo K, Gholami Z, Shaffer D, Stone S, Bayer S, Wray C, Bogden R, Dayananth P, Ward J, Tonin P, Narod S, Bristow PK, Norris FH, Helvering L, Morrison P, Rosteck P, Lai M, Barrett JC, Lewis C, Neuhausen S, CannonAlbright L, Goldgar D, Wiseman R, Kamb A, Skolnick MH. A strong candidate for the breast and ovarian cancer susceptibility gene BRCA1. Science 1994; 266:66-71.

3 Wooster R, Bignell G, Lancaster J, Swift, S, Seal S, Mangion J, Collins N, Gregory S, Gumbs C, Micklem G, Barfoot R, Hamoudi R, Patel S, Rice C, Biggs $P$, Hashim $Y$, Smith A, Conner F, Arason A, Gudmundsson J, Ficenec D, Kelsell D, Ford D, Tonin P, Bishop DT, Spurr NK, Ponder BAJ, Eeles R, Peto J, Devilee P, Cornelisse C, Lynch H, Narod S, Lenoir G, Egilsson V, Barkadottir $R B$, Easton DF, Bentley DR, Futreal PA, Ashworth A, Stratton MR. Identification of the breast cancer susceptibility gene BRCA2. Nature 1995;378:789-92.

4 Tavtigian SV, Simard J, Rommens J, Couch F, Shattuck-Eidens D, Neuhausen S, Meraiver S, Thorlacius S, Offit K, Stoppa-Lyonnet D, Belanger $C$, Bell R, Berry $S$, Bogden R, Chen Q, Davis T, Dumont $M$, Frye $C$ Hattier T, Jammulapati S, Janecki T, Jiang P, Kehrer R, Leblanc J-F, Mitchell JT, McArthur-Morrison J, Nguyen K, Peng Y, Samson C, Schroeder M, Snyder SC, Steele L, Stringfellow M, Stroup C, Swedlund B, Swensen J, Teng D, Thomas A, Tran T, Tranchant M, Weaver-Feldhaus J, Wong AKC, Shizuya H, Eyfjord JE, Cannon-Albright L, Labrie F, Skolnick MH, Weber B, Kamb A, Goldgar DE. The complete BRCA2 gene and mutations in chromosome 13q-linked kindreds. Nat Genet 1996;12:333-7.

5 Narod SA, Boyd J. Current understanding of the epidemiology and clinical implications of BRCA1 and BRCA2 mutations for ovarian cancer. Curr Opin Obstet Gynecol 2002;14:19-26.

6 Robson ME, Boyd J, Borgen PI, Cody HS. Hereditary breast cancer. Curr Prob Surg 2001:38:377-480.

7 Blackwood MA, Weber BL. BRCA1 and BRCA2: from molecular genetics to clinical medicine. J Clin Oncol 1998;16:1969-77.

8 Breast Cancer Information Core Database. Available at: http:// research.nhgri.nih.gov/bic.

9 Struewing JP, Abeliovich D, Peretz T, Avishai N, Kaback MM, Collins FS, Brody LC. The carrier frequency of the BRCA1 185delAG mutation is approximately $1 \%$ in Ashkenazi Jewish individuals. Nat Genet 1995:11:198-200.

10 Oddoux C, Struewing JP, Clayton CM, Neuhausen S, Brody LC, Kaback M, Haas B, Norton L, Borgen P, Jhanwar S, Goldgar D, Ostrer H, Offit K. The carrier frequency of the BRCA2 6174 delT mutation among Ash'kenazi Jewish individuals is approximately 1\%. Nat Genet 1996;14:188-90.

11 Roa BB, Boyd AA, Volcik K, Richards CS. Ashkenazi Jewish population frequencies for common mutations in BRCA1 and BRCA2. Nat Genet 1996; 14:185-7.

12 Warner E, Foulkes W, Goodwin P, Meschino W, Blondal J, Paterson C, Ozcelik H, Goss P, Allingham-Hawkins D, Hamel N, Di Prospero L, Contiga V, Serruya C, Klein M, Moslehi R, Honeyford J, Liede A, Glendon G, Brunet JS, Narod S. Prevalence and penetrance of BRCA1 and BRCA2 gene mutations in unselected Ashkenazi Jewish women with breast cancer. J Natl Cancer Inst 1999;91:1241-7.

13 Johannesdottir G, Gudmundsson J, Bergthorsson JT, Arason A, Agnarsson $B A$, Eiriksdottir $G$, Johannsson OT, Borg $A$, Ingvarsson $S$ Easton DF, Egilsson V, Barkardottir RB. High prevalence of the 999 del5 mutation in Icelandic breast and ovarian cancer patients. Cancer Res 1996;56:3663-5

14 Thorlacius S, Sigurdsson S, Biarnadottir H, Olafsdottir G, Jonasson JG, Tryggvadottir L, Tulinius H, Eyfiord JE. Study of a single BRCA2 mutation with high carrier frequency in a small population. Am J Hum Genet 1997;60:1079-84.

15 Langston AA, Malone KE, Thompson JD, Dalin JR, Ostrander EA. BRCAI mutations in a population-based sample of young women with breast cancer N Engl J Med 1996;334:137-42.
16 Couch FJ, DeShano ML, Blackwood MA, Calzone K, Stopfer J, Campeau L, Ganguly A, Rebbeck T, Weber BL. BRCA1 mutations in women attending clinics that evaluate the risk of breast cancer. N Engl J Med 1997;336: 1409-15.

17 Krainer M, Silva-Arrieta S, Fitzgerald MG, Shimada A, Ishioka C, Kanamaru R, MacDonald DJ, Unsal H, Finkelstein DM, Bowcock A Issellbacher KJ, Haber DA. Differential contributions of BRCA1 and BRCA2 to early-onset breast cancer. N Engl J Med 1997;336:1416-21.

18 Eccles DM, Englefield P, Soulby MA, Campbell IG. BRCA1 mutations in southern England. Br J Cancer 1998:77:2199-2203.

19 Peto J, Collins N, Barfoot R, Seal S, Warren W, Rahman N, Easton DF, Evans C, Deacon J, Stratton MR. Prevalence of BRCA1 and BRCA2 gene mutations in patients with early-onset breast cancer. I Natl Cancer Inst 1999:91:943-9.

20 Malone KE, Daling JR, Neal C, Suter NM, O'Brien C, Cushing-Haugen K, Jonasdottir TJ, Thompson JD, Ostrander EA. Frequency of BRCA1/BRCA2 mutations in a population-based sample of young breast carcinoma cases. Cancer 2000;88:1393-1402.

21 Anglian Breast Cancer Study Group. Prevalence and penetrance of BRCA1 and BRCA2 mutations in a population-based series of breast cancer cases. BrJ Cancer 2000;83:1301-8.

22 Newman B, Mu H, Butler LM, Millikan RC, Moorman PG, King MC. Frequency of breast cancer attributable to BRCA1 in a population-based series of American women. J Am Med Assoc 1998;279:915-21.

23 Garcia-Patino E, Gomendio B, Provencio M, Silva JM, Garcia JM, Espana P, Bonilla F. Germ-line BRCA1 mutations in women with sporadic breast cancer: clinical correlations. J Clin Oncol 1998;16:1 15-20.

24 Tang NL, Pang CP, Yeo W, Choy KW, Lam PK, Suen M, Law LK, King WW, Johnson $P$, Hielm M. Prevalence of mutations in the BRCAl gene among Chinese patients with breast cancer. J Natl Cancer Inst 1999;91:882-5.

25 Lancaster JM, Wooster R, Mangion J, Phelan CM, Cochran C, Gumbs C Seal S, Barfoot R, Collins N, Bignell G, Patel S, Hamoudi R, Larsson C, Wiseman RW, Berchuck A, Iglehart JD, Marks JR, Ashworth A, Stratton MR, Futreal PA. BRCA2 mutations in primary breast and ovarian cancers. Nat Genet 1996;13:238-40

26 Weber BH, Brohm M, Stec I, Backe J, Caffier H. A somatic truncating mutation in BRCA2 in a sporadic breast tumor. Am J Hum Genet 1996;59:962-4.

27 Andrulis IL, Anton-Culver H, Beck J, Bove B, Boyd J, Buys S, Godwin AK, Hopper IL, Li F, Neuhausen SL, Ozcelik H, Peel D, Santella RM, Southey MC, van Orsouw NJ, Venter DJ, Viig J, Whittemore AS. Comparison of DNA- and RNA-based methods for detection of truncating BRCA1 mutations. Hum Mutat 2002;20:65-73.

28 Nordling M, Karlsson P, Wahlstrom J, Engwall Y, Wallgren A, Martinsson T. A large deletion disrupts the exon 3 transcription activation domain of the BRCA2 gene in a breast/ovarian cancer family. Cancer Res 1998;58:1372-5.

29 Berman DB, Costalas J, Schultz DC, Grana G, Daly M, Godwin AK. A common mutation in BRCA2 that predisposes to a variety of cancers is found in both Jewish Ashkenazi and non-Jewish individuals. Cancer Res 1996;56:3409-14.

30 Fodor FH, Weston A, Bleiweiss IJ, McCurdy LD, Walsh MM, Tartter Pl, Brower ST, Eng CM. Frequency and carrier risk associated with common BRCA1 and BRCA2 mutations in Ashkenazi Jewish breast cancer patients. Am J Hum Genet 1998;63:45-51.

31 Verhoog LC, Berns EM, Brekelmans CT, Seynaeve C, Meijers-Heijboer EJ, Kliin JG. Prognostic significance of germline BRCA2 mutations in hereditary breast cancer patients. J Clin Oncol 2000;18(suppl 21):S119-24.

32 Easton DF. How many more breast cancer predisposition genes are there? Breast Cancer Res 1999;1:14-7.

33 Peto J. Breast cancer susceptibility-a new look at an old model. Cancer Cell 2002;1:411-12.

34 Peto J, Mack TM. High constant incidence in twins and other relatives of women with breast cancer. Nat Genet 2000;26:41 1-14.

35 Peto J. Cancer epidemiology in the last century and next decade. Nature 2001;411:390-5.

36 Pharoah PDP, Antoniou A, Bobrow M, Zimmern RL, Easton DF, Ponder BA Polygenic susceptibility to breast cancer and implications for prevention. Nat Genet 2002;31:33-6.

37 Dunning AM, Healey CS, Pharoah PDP, Teare MD, Ponder BA, Easton DF. A systematic review of genetic polymorphisms and breast cancer risk. Cancer Epidemiol Biomarkers Prev 1999:8:843-54.

38 Coughlin SS, Piper M. Genetic polymorphisms and risk of breast cancer. Cancer Epidemiol Biomarkers Prev 1999;8:1023-32.

39 Cardon LR, Bell Jl. Association study designs for complex diseases. Nat Rev Genet 2001;2:91-9.

40 Cheung VG, Spielman RS. The genetics of variation in gene expression. Nat Genet 2002;32(suppl):522-5. 